\title{
THE DICTYATE OOCYTE OF MICROTUS MONTANUS
}

\author{
P. G. GROSS* \\ Biology Department, Tulane University, \\ New Orleans, Louisiana 70118, U.S.A.
}

(Received 23rd November 1970)

The resumption of mammalian oocyte nuclear maturation following oocyte growth has been typically defined as: (1) the first change in oocyte morphology after the completion of the single 'resting' dictyate stage, and/or (2) changes in the oocyte initiated at the time of ovulatory stimulation. It seemed of interest to report striking changes in the dictyate oocyte which were associated with follicle development rather than ovulatory stimulation in the field vole, Microtus montanus.

Ten mature (open vagina) virgin females were selected from a breeding colony of $M$. montanus. One ovary from each female was fixed in alcoholformalin-acetic acid, embedded in Tissue-mat and serially sectioned at $10 \mu \mathrm{m}$. Sections were stained with Harris' haematoxylin and eosin for general morphology and Schiff's reagent and fast green (Feulgen) for chromosomal studies. Only oocytes contained within normal follicles (absence of pycnotic granulosa cells) were examined. The sequence of observed morphological changes occurred in all females examined and therefore no distinction was made between females stimulated to ovulate and those not stimulated to ovulate (see Firmin, 1968).

Two distinct dictyate stages of meiosis were observed. The term, dictyate, was used for both stages since the Feulgen positive material, chromatin, remained diffuse in comparison to the subsequent highly condensed chromatin of diakinesis. The two dictyate stages were associated with the stage of follicle development as shown in Table 1.

The early dictyate stage (Pl. 1, Fig. 1) was found in oocytes at all phases of growth within preantral follicles. At maximum size, approximately $60 \mu \mathrm{m}$ in diameter, the spherical oocyte has a large centrally placed, regularly outlined nucleus and a homogeneous cytoplasm. The nucleus contained a single eccentric nucleolus, approximately one-fourth the diameter of the nucleus, which stained strongly with haematoxylin. The heterogeneous nucleoplasm consisted of a fine granular matrix with thin threads and small globules of chromatin, somewhat more localized at the nuclear membrane and the periphery of the nucleolus.

When the oocytes had completed the majority of their growth and the antrum was initiating formation in the corresponding follicles, the late dictyate sequence was observed. The oocyte assumed a more ovoid shape, the nucleus

* Present address: Laboratory of Reproductive Physiology, School of Veterinary Medicine, University of Pennsylvania, Lippincott Building, 25th and Locust Streets, Philadelphia, Pennsylvania 19104. 
elongated and moved to the periphery of the oocyte, and an achromatic region was found surrounding the nucleus and in the peripheral cytoplasm. After staining with haematoxylin, small nucleolar-like bodies, micronucleoli, were observed in the vicinity of the principal nucleolus and migrated to the nuclear membrane (Pl. 1, Fig. 2). As the size of the larger nucleolus diminished, the number of micronucleoli increased until bodies of equal size were symmetrically arranged in the peripheral nucleoplasm (Pl. 1, Fig. 3). The micronucleoli eventually diminished in size and became more numerous.

Simultaneously with the appearance and peripheral movement of the micronucleoli, the nucleoplasm became less well defined. The chromatin material condensed around the nuclear membrane and peripheral micronucleoli as the nucleus flattened with the disappearance of the nucleoplasm.

TABLE 1

NUMBER OF OOCYTES IN DIFFERENT STAGES OF THE DICTYATE SEQUENCE AS ASSOGIATED WITH THE STAGE OF FOLLICLE DEVELOPMENT

\begin{tabular}{|c|c|c|c|c|c|}
\hline & \multirow{3}{*}{$\begin{array}{l}\text { Stage of dictyate sequence } \\
\text { (nuclear characteristics) }\end{array}$} & \multicolumn{4}{|c|}{ Stage of follicle development* } \\
\hline & & \multirow[b]{2}{*}{ Preantral } & \multicolumn{3}{|c|}{ Antral } \\
\hline & & & $\begin{array}{c}\text { Initial } \\
\text { antrum } \\
\text { formation }\end{array}$ & $\begin{array}{l}\text { Antrum on } \\
\text { two sides } \\
\text { of oocyte }\end{array}$ & $\begin{array}{l}\text { Antrum on } \\
\text { three sides } \\
\text { of oocyte }\end{array}$ \\
\hline Position & $\begin{array}{l}\text { Eccentric (P1. 1, Fig. 1) } \\
\text { Peripheral (P1. 1, Figs 1, 2) }\end{array}$ & $\begin{array}{r}20 \\
0\end{array}$ & $\begin{array}{r}4 \\
16\end{array}$ & $\begin{array}{r}0 \\
20\end{array}$ & $\begin{array}{r}0 \\
20\end{array}$ \\
\hline Nucleoplasm & $\begin{array}{l}\text { Fine granular matrix (Pl. 1, } \\
\text { Fig. 1) } \\
\text { Empty (Pl. 1, Figs 2, 3) }\end{array}$ & $\begin{array}{r}20 \\
0\end{array}$ & $\begin{array}{r}7 \\
13\end{array}$ & $\begin{array}{r}0 \\
20\end{array}$ & $\begin{array}{r}0 \\
20\end{array}$ \\
\hline Nucleoli & $\begin{array}{l}\text { One large (Pl. 1, Fig. 1) } \\
\text { One large, a few smaller } \\
\text { (Pl. 1, Fig. 2) } \\
\text { Several small, peripherally } \\
\text { arranged (Pl. 1, Fig. 3) }\end{array}$ & $\begin{array}{r}20 \\
0 \\
0\end{array}$ & $\begin{array}{r}11 \\
9 \\
0\end{array}$ & $\begin{array}{r}2 \\
12 \\
6\end{array}$ & $\begin{array}{r}0 \\
0 \\
20\end{array}$ \\
\hline
\end{tabular}

* Twenty follicles of each type were examined and the nuclear condition of the oocytes was characterized. These data were compiled from examining ten ovaries from ten females.

The number of micronucleoli increased as their size decreased. Following the disappearance of these bodies, condensed chromosomes, characteristic of diakinesis, were observed in the vicinity of the nuclear membrane (Pl. 1, Fig. 4).

The sequence of changes in the morphology of the oocyte nucleus and cytoplasm which is reported in this study represents the only detailed description in a mammalian species of events taking place between the dictyate stage characteristic of oocyte growth and the initial condensation of the chromosomes, diakinesis. This sequence is probably not unique to $M$. montanus since isolated observations of the dictyate stage in other mammalian species correspond to parts of the sequence (i.e. mouse, Griffin, 1966; rat, Odor, 1955; Mandl, 1963). The most interesting observation concerned the striking changes in the size, position and number of nucleolar-like bodies. The absence of 
PL.ATE 1

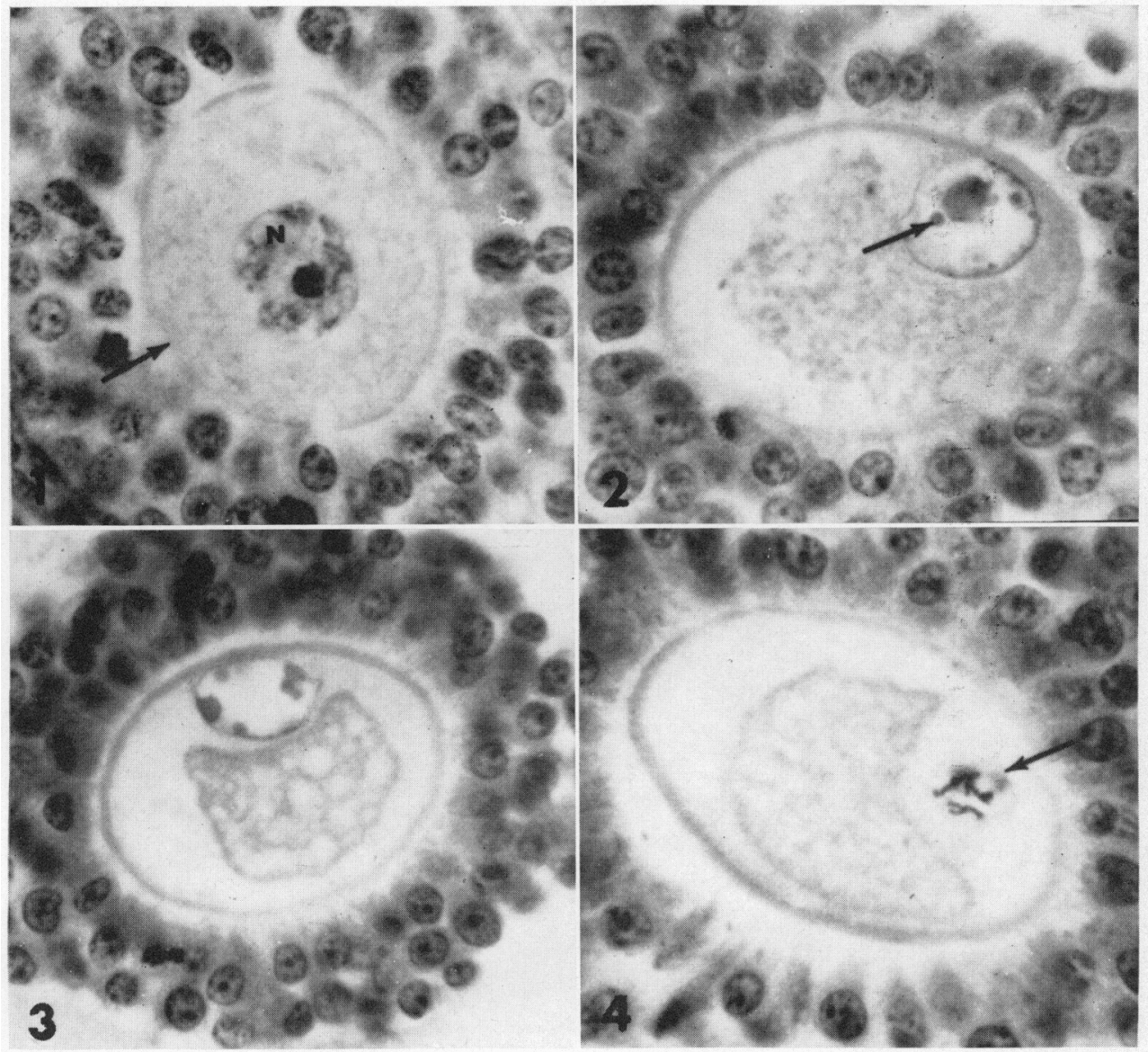

Fig. 1. Early dictyate oocyte. The oocyte is surrounded by the zona peliucida (arrow) and contains a centrally placed nucleus $(N)$ with diffuse chromatin material and a single darkly staining nucleolus. $\mathrm{H} \& \mathrm{E}, \times 670$.

FIG. 2. Late dictyate oocyte. The nucleus has moved to the periphery of the oocyte and micronucleoli (arrow) can be seen in the vicinity of the large nucleolus. $\mathrm{H} \& \mathrm{E}, \times 670$.

FIG. 3. Late dictyate oocyte. The micronucleoli have increased in size and are arranged at the nuclear membrane. $\mathrm{H} \& \mathrm{E}, \times 670$.

Fig. 4. Oocyte in diakinesis. Individual tetrads can be observed within the intact nuclear membrane (arrow). H \& E, $\times 670$. 
staining with the Feulgen technique demonstrates that these bodies are not primarily deoxyribonucleic acid and do not represent previously reported circular chromosomal arrangements at diakinesis (Donahue, 1968); equally, any statement regarding their composition should not be based solely on their affinity for haematoxylin (see Austin, 1961). It is likely, however, that these gross morphological changes are manifestations of changes in metabolic activity.

Nucleolar phenomena have been reported during the oogenesis of several species (see Raven, 1961); however, the changes reported here are of particular interest in relationship to the point in oocyte development in which they occur. A change in the metabolism of the oocyte might be expected at this stage of development since the oocyte is shifting from a period of synthesis and growth to the period of relative quiescence acquired before fertilization. In amphibians, this period of oogenesis is associated with heterogeneous RNA synthesis (Brown \& Littna, 1964). Furthermore, Brachet (1965) observed nucleolar changes in the amphibian oocyte at this stage and suggests that these changes may be indications of the RNA synthesis reported by Brown \& Littna (1964).

In the present study, the early dictyate stage was only found in preantral follicles; the late dictyate sequence was associated with the formation and development of the antrum in the corresponding follicles. Indications of meiotic resumption at antrum formation have also been observed in the rat (Kirkham \& Burr, 1913) and the rabbit (Pincus \& Enzmann, 1937). The association made between the follicle and meiotic resumption is not meant to suggest a causal relationship since it is possible that the oocyte is programmed to resume meiosis when it completes most of its growth. It does appear, however, that, in $M$. montanus, meiotic resumption is not dependent upon ovulatory stimulation which in this species is dependent upon the male (Firmin, 1968).

This study was supported by NIH Training Grant 5T1-GM 669. The field voles were kindly provided by $\mathrm{Dr}$ N. C. Negus, Tulane University.

\section{REFERENCES}

Austin, C. R. (1961) The mammalian egg. Blackwell Scientific Publications, Oxford.

BRACHET, J. (1965) Emission of Feulgen-positive particles during the in vitro maturation of toad ovocytes. Nature, Lond. 208, 596.

Brown, D. D. \& Litrna, E. (1964) RNA synthesis during the development of Zenopus laevis, the South African clawed toad. $\mathcal{F}$. molec. Biol. 8, 669 .

Donamue, R. P. (1968) Maturation of the mouse oocyte in vitro. I. Sequence and timing of nuclear progression. 7. exp. Zool. 169, 237.

FiRmin, P. C. (1968) The response of oocytes and follicles to artificial and natural ovulatory stimulation in the field vole, Microtus montanus. Ph.D. thesis, Tulane University, New Orleans, La.

Griffin, A. B. (1966) Nuclear cytology. In: Biology of the Laboratory Mouse, 2nd edn. Ed. E. L. Green. McGraw-Hill, New York.

KrRkHAM, W. B. \& BURR, H. S. (1913) The breeding habits, maturation of eggs and ovulation of the albino rat. Am. F. Anat. 15, 291.

Mande, A. M. (1963) Preovulatory changes in the oocyte of the adult rat. Proc. R. Soc. B, 158, 105.

ODOR, D. L. (1955) The temporal relationship of the first maturation division of rat ova to the onset of heat. Am. F. Anat. 97, 461.

Pincus, G. \& ENZMANN, E. V. (1937) The growth, maturation and atresia of ovarian eggs in the rabbit. 7. Morph. 61, 351 .

Raven, C. P. (1961) Oogenesis: the storage of developmental information. MacMillan, New York. 